\title{
PENINGKATAN HASIL BELAJAR BAHASA INDONESIA MELALUI PEMBELAJARAN PROBLEM BASED LEARNING (PBL) KELAS XI MM 1 MATERI TEKS PROSEDUR SMK NEGERI 7 PEKANBARU TAHUN PELAJARAN 2017
}

\author{
(Improvement of Indonesian Language Learning through Problem Based Learning (PBL) for Class
}

XI MM I on Procedure Text at SMK Negeri 7 Pekanbaru academic year2017)

\author{
Oleh: Ali Askar*) \\ *) Guru Bahasa Indonesia SMK Negeri 7 Pekanbaru
}

\begin{abstract}
.
Language Learning Indonesian students must understand the learning material because of the Problem Based Learning (Pbl) model ) This stimulates students to learn through various myata problems in daily life, associated with knowledge that has been or will be studied, so each student must understand and understand the circumstances of the surrounding environment. In addition, student motivation also arises because of the Problem Based model Learning is held as a group award, this rewerd is a motivation that fosters students' desire to excel during learning The application of the Problem Based Learning (Pbl) learning model is considered effective enough to improve student learning outcomes, As research has done by Yunin Nurnn Nafiah (2014) with applying the PbI Problem poseg learning model) in PC Repair and Re-setting subjects, can improve student learning outcomes Nisaul Azmi Hajar, et al (2016) by applying the Problem Based Learning (Pbl) learning method in Sociology subjects, can improve student learning outcomes by $80.86 \%$ Based on the description above, conducted about the Problem Based Learning (Pbl) learning model in the process of learning Indonesian with a research proposal entitled "Improvement of Indonesian Language Learning Through Problem Based Learning (Pbl) Learning Class MM I on Procedures Text at Vocational High School 7 Pekanbaru in 2017 Academic Year based on the results of research and discussion, as well as data analysis that has been described in IV can be concluded that: The use of the Problem Based Learning (Pbl) method for Indonesian language lessons with a total of six meetings in class XI MM 1 at SMK Negen 7 Pekanbaru in the 2017-2018 academic year can improve learning outcomes a syndrome from an average of 77, 59 in the first cycle to an average of 85.52 in the IE cycle. The increase in student learning outcomes increased significantly with the addition of the percentage of students who scored $>82$ ie 19 people from 30 people in the first cycle to 25 people from 30 people in the first cycle which were categorized as complete. This illustrates that the use of the group investigation method is optimal to improve the learning outcomes of Indonesian students in class XII IPS 1 of SMK Negeri 7 Pekanbaru in the academic year 2017-2018.
\end{abstract}

Keywords: Model Problem Based Learning (Pbl), Classroom Action Research

\section{PENDAHULUAN}

Belajar adalah proses perubahan perilkau berkat pengalaman dan latihan. Artinya tujuan kegiatan adalah perbuhan tingkah laku, baik yang menyangkut pengetahuan, keterampilan sikap, bahkan meliput segenap aspek organisme atau pribadi (Djamarah, 2006). Pembelajaran bahasa Indonesia peserta didik harus memahami materi pembelajaran karena pada model Problem Based Learning ( $\mathrm{Pbl}$ ) ini merangsang peserta didik untuk belajar melalui berbagai permasalahan nyata dalam kehidupan sehari-hari, dikaitkan dengan pengetahuan yang telah atau akan dipelajarinya, maka setaiap siswa harus paham dan mengerti dengan keadaan lingkungan sekitar. Selain itu, motivasi 
belajar siswa juga timbul karena pada model Problem Based Learning diadakan penghargaan kelopmpok, rewerd ini menjadi suatu motivasi yang menumbuhkan keinginan siswa untuk berprestasi selama pembelajaran.

Penerapan model pembalajaran Problem Based Learning ( $\mathrm{Pbl}$ ) dinilai cukup efektif untuk meningkatkan hasil belajar peserta didik. Sebagaimana penelitian yang telah dilakukan Yunin Nurun Nafiah (2014) dengan menerapkan model pembelajaran Problem Based Learning ( $\mathrm{Pbl}$ ) pada mata pelajaran Perbaikan dan Setting Ulang PC, dapat meningkatkan hasil belajar siswa. Nisaul Azmi Hajar, dkk (2016) dengan menerapkan model pembelajaran Problem Based Learning ( $\mathrm{Pbl}$ ) pada mata pelajaran Sosiologi, dapat meningkatkan hasil belajar siswa sebesar 80,86 \%. Berdasarkan uraian di atas, dilakukan penelitian tentang model pembelajaran Problem Based Learning (Pbl) dalam proses pembalajaran bahasa Indonesia dengan suatu usulan penelitian yang berjudul "Peningkatan Hasil Belajar Bahasa Indonesia Melalui Pembelajaran Problem Based Learning ( $\mathrm{Pbl}$ ) Kelas XI MM 1 Materi Teks Prosedur SMK Negeri 7 Pekanbaru Tahun Pelajaran 2017'. Berdasarkan uraian latar belakang dapat dirumuskan sebagai berikut : bagaimanakah model pembelajaran Problem Based Learning ( $\mathrm{Pbl}$ ) dapat meningkatkan hasil belajar belajar bahasa Indonesia pada materi teks prosedur di kelas XI MM 1 SMKN 7 Pekanbaru? Berdasarkan rumusan masalah yang telah dikemukakan, maka penelitian ini bertujuan untuk meningkatkan hasil belajar bahasa Indonesia pada materi kalimat Tanya dengan menerapkan model pembalajaran Problem Based Learning (Pbl) di kelas XI MM 1 SMK Negeri 7 Pekanbaru.

Manfaat teoritis hasil penelitian ini diharapkan dapat menjadi referensi atau masukan bagi pengembangan ilmu pengetahuan yaitu menerapkan model pembalajaran Problem Based Learning (Pbl) untuk penelitian tindakan elas dibidang pembalajaran bahasa Indonesia di eklas XI MM tingkat SMK. Manfaat praktis Bagi siswa, untuk meningkatkan peran aktif siswa selama proses pembalajaran, meningkatkan kemampuan siswa dalam mengemukakakn pendapat saat diskusi, melatih siswa untuk bekerjasama, meningkatkan rasa tanggung jawab siswa terhadap pembelajaran serta meningkatkan hasil belajar siswa pada pembelajaran bahasa Indonesia. Bagi guru, dapat dijadikan alternative pemecahan masalah dalam suatu pembelajaran serta menjadi referensi ilmiah bagi guru untuk melaksanakan perbaikan proses pembelajaran bahasa Indonesia pada materi teks prosedur. Bagi sekolah, dapat dijadikan salah satu bahan masukan untuk meningkatkan kualitas pembelajaran bahasa Indonesia di sekolah serta menambah referensi tentang PTK di Perpustakaan sekolah.

\section{Defenisi Operasional}

Konsep bahasa Indonesia yang digunakan dalam penelitian ini adalah model pembelajaran Problem Based Learning ( $\mathrm{Pbl})$. Model pembalajaran yang digunakan dalam penelitian ini adalah Problem Based Learning (Pbl).Penelitian ini dilakukan pada siswa kelas XI MM 1 dengan materi kalimat tanya pada semester ganjil 2017.

\section{METODE PENELITIAN}

Penelitian ini merupakan penelitian tindakan (action research), karena penelitian ini dilakukan untuk memecahkan masalah pelajaran di kelas. Penelitian ini juga termasuk penelitian deskriptif, sebab menggambarkan bagaimana suatu tekhnik pembalajaran diterapkan dan bagaimana hasil yang diinginkan dapat dicapai.

Menurut Oja dan Sumarjan (dalam Titik Sugiarti, 1997) mengelompokkan penelitian menjadi empat kelompok yaitu (a) guru sebagai peneliti, (b) penelitian tindakan kolaboratif, (c) simultan teintegratif, (d) adminitratif sosial eksperimental. Penelitian dilaksanakan bulan Agustus 2017 sampai bulan 
November 2017, semester ganjil tahun pelajaran 2017-2018. Waktu ini meliputi kegiatan persiapan sampai penyusunan laporan penelitian. Penelitian ini dilaksanakan di SMK Negeri 7 Pekanbaru yang beralamatkan di Jalan Yos sudarso Rumbai kota Pekanbaru.

Penelitian ini difokuskan pada kelas XI MM 1, berjumlah 30 orang yang terdiri dari 10 orang laki-laki dan 20 orang perempuan. Penelitian ini menggunakan rancangan penelitian tindakan kelas (classroom action research). Dasar pelaksanaan tindakan kelas dari siklus I ke siklus berikutnya didasarkan peningkatan motivasi dan pencapaian nilai KKM 75. Pelaksanaan pembelajaran bahasa Indonesia metode Problem Based Learning (Pbl) dilaksanakan sebanyak dua siklus. Secara umum alaur tindakan dalam penelitian tindakan kelas ini digambarkan oleh Kemmis dan Mc. Taggart (1988) sebagai berikut:

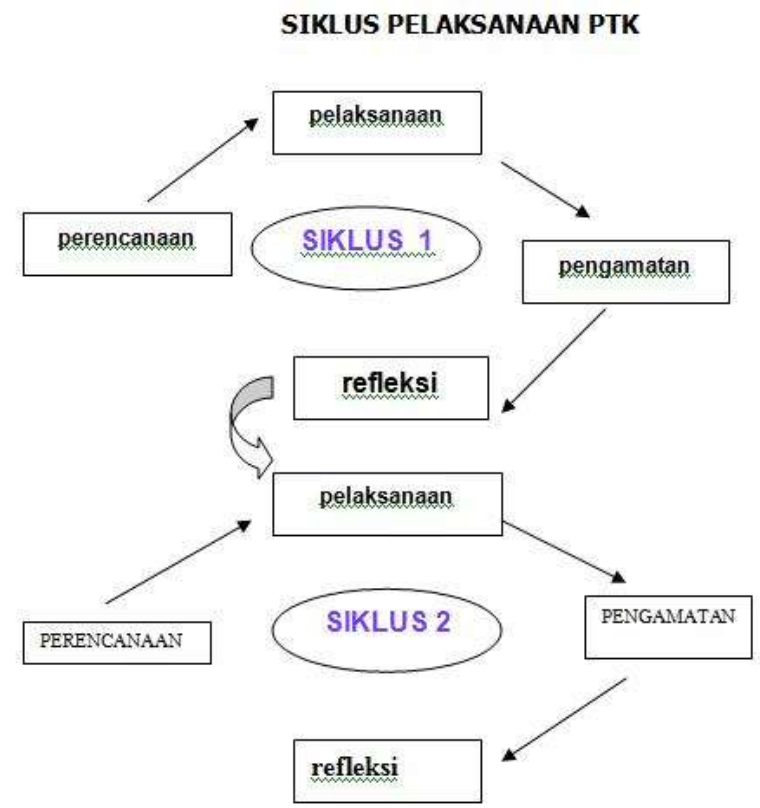

Berdasarkan hasil penelitian dan pembahasan, serta analisa data yang telah diuraikan pada bab IV dapat disimpulkan bahwa: Penggunaan metode Problem Based Learning $(\mathrm{Pbl})$ untuk pembelajaran bahasa Indonesia dengan jumlah enam kali pertemuan di kelas XI MM 1 SMK Negeri 7 Pekanbaru tahun pelajaran 2017-2018 dapat meningkatkan hasil belajar Bahasa Indoensia dari rata-rata 77,59 pada siklus I menjadi rata-rata 85,52 pada siklus II. Peningkatan hasil belajar siswa meningkat secara signifikan dengan adanya penambahan persentase siswa yang memperoleh nilai $\geq 82$ yaitu 19 orang dari 30 orang pada siklus I menjadi 25 orang dari 30 orang pada siklus II yang dikategorikan tuntas. Hal ini menggambarkan bahwa penggunaan metode Problem Based Learning (Pbl) untuk meningkatkan hasil belajar pembelajaran bahasa Indonesia sudah optimal di kelas XII IPS 1 SMK Negeri 7 Pekanbaru tahun pelajaran 2017-2018

Pembelajaran menggunakan metode Problem Based Learning (Pbl) memberikan hasil yang positif terhadap peningkatan hasil belajar siswa dibandingkan dengan menggunakan pembelajaran konvensional di SMK Negeri 7 Pekanbaru. Pada dasarnya penelitian ini berimplikasi positif bagi siswa dimana terlihat siswa akan lebih aktif, merasa percaya diri dan mandiri dalam mengikuti proses pembelajaran. Selain itu dapat juga sebagai pendorong bagi tenaga guru di SMA Negeri 2 Pekanbaru untuk memanfaatkan metode pembelajaran Problem Based Learning (Pbl) sebagai metode untuk menunjang proses pembelajaran.

Sebagai pendidik, guru harus menyadari bahwa kemajuan pembelajaran Bahasa Indonesia lebih bergantung pada dedikasi guru serta kreativitasnya setelah mengetahui perubahan-perubahan dan perkembangan yang terjadi di berbagai tempat. Oleh karena itu, dengan memperhatikan kenyataan ini dan menyadari siswa akan hidup dalam kurun waktu yang penuh persaingan untuk selalu memperbaharui pelajaran dan pembelajaran. Dengan menggunakan metode Problem Based Learning (Pbl), guru diharapkan dapat memberikan makna belajar bagi siswa terutama dalam pembelajaran bahasa Indonesia, dalam hal ini dapat memahami setiap materi pembelajaran dan mencari makna setiap apa yang mereka ketahui melalui tahapan 
pembelajaran dalam metode Problem Based Learning (Pbl).

Berdasarkan penelitian ini memberikan masukan pada peneliti dan sekolah bahwa metode Problem Based Learning $(\mathrm{Pbl})$ merupakan pilihan yang tepat bagi guru untuk menciptakan pembelajaran yang menarik dan menyenangkan agar siswa lebih aktif dan semakin bersemangat dalam belajar serta mudah memahami materi pembelajaran bahasa Indonesia. Dengan demikian dapat disimpulkan bahwa metode Problem Based Learning (Pbl) dapat dijadikan sebagai salah satu pilihan untuk memperbaiki dan meningkatkan hasil belajar bahasa Indonesia siswa.

\section{Hasil Penelitian Siklus 1}

Hasil belajar yang diperoleh peserta didik pada siklus I yang didapatkan oleh peneliti, adalah sebagai berikut:

Hasil Belajar Peserta didik Siklus I

\begin{tabular}{|c|l|c|}
\hline No & \multicolumn{1}{|c|}{ Hasil Belajar } & Pencapaian Siklus I \\
\hline 1 & Nilai Terendah & 50,00 \\
\hline 2 & Nilai Tertinggi & 95,00 \\
\hline 3 & $\begin{array}{l}\text { Nilai Rata-rata } \\
\text { Kelas }\end{array}$ & 77,59 \\
\hline 4 & $\begin{array}{l}\text { Jumlah Peserta } \\
\text { didik nilai } \geq 75\end{array}$ & 19 \\
\hline 5 & $\begin{array}{l}\text { Jumlah Peserta } \\
\text { didik }\end{array}$ & 29 \\
\hline 6 & $\begin{array}{l}\text { Persentase } \\
\text { Mendapat Nilai } \geq \\
75\end{array}$ & $65,52 \%$ \\
\hline
\end{tabular}

Hasil belajar peserta didik pada siklus I yang terlihat pada tabel 2 menunjukkan bahwa jumlah peserta didik yang mempunyai nilai diatas 75 hanya $65,52 \%$. Berdasarkan hasil belajar dan penilaian terhadap tes siklus I diperoleh bahwa:

1. Pelaksanaan pembelajaran teks prosedur dengan metode Problem Based Learning (Pbl) pada siklus I ini peserta didik mempunyai nilai rata-rata 77,59.

2. Pembelajaran teks prosedur dengan metode Problem Based Learning (Pbl) yang mendapat nilai $\geq 82$ hanya $65,52 \%$.
${ }^{7}$ Ini menunjukkan bahwa hasil belajar teks prosedur peserta didik dengan metode Problem Based Learning ( $\mathrm{Pbl}$ ) pada siklus I secara klasikal belum sesuai dengan yang diharapkan dalam penelitian ini.

\section{Siklus 2}

Tes hasil belajar peserta didik yang dilakukan akhir siklus II, diperoleh data sebagai berikut:

Tabel 2. Hasil Belajar Peserta didik Siklus II

\begin{tabular}{|c|l|c|}
\hline No & Hasil Belajar & Pencapaian Siklus II \\
\hline 1 & Nilai Terendah & 65,00 \\
\hline 2 & Nilai Tertinggi & 100 \\
\hline 3 & $\begin{array}{l}\text { Nilai Rata-rata } \\
\text { Kelas }\end{array}$ & 85,52 \\
\hline 4 & $\begin{array}{l}\text { Jumlah Peserta } \\
\text { didik nilai } \geq 75\end{array}$ & 25 orang \\
\hline 5 & $\begin{array}{l}\text { Jumlah Peserta } \\
\text { didik }\end{array}$ & 29 orang \\
\hline 6 & $\begin{array}{l}\text { Persentase } \\
\text { Mendapat Nilai } \\
\geq 75\end{array}$ & $86,21 \%$ \\
\hline
\end{tabular}

Tabel di atas memperlihatkan jumlah peserta didik yang telah mendapat nilai diatas 75 sebanyak 26 orang dari 29 orang atau sebesar $86,21 \%$. Berdasarkan hasil belajar dan penilaian terhadap tes siklus II diperoleh bahwa:

1. Pelaksanaan pembelajaran teks prosedur dengan metode Problem Based Learning ( $P b l)$ pada siklus II ini peserta didik mempunyai nilai rata-rata 85,52 .

2. Pembelajaran teks prosedur dengan metode Problem Based Learning (Pbl) yang mendapat nilai $\geq 75$ hanya $86,21 \%$.

Dari hasl belajar siklus II, menunjukkan bahwa nilai yang memperoleh nilai diatas 75 sudah lebih dari 80\%. Maka dapat disimpulkan bahwa pembelajaran bahasa Indonesia menggunakan metode Problem Based Learning $(\mathrm{Pbl})$ pada penelitian ini sudah cukup memadai sampai pada tindakan siklus II saja. 


\section{Pembahasan}

Berdasarkan hasil belajar yang dicapai pada siklus I dan Siklus II, peningkatan persentase hasil belajar peserta didik dengan metode Problem Based Learning (Pbl) pada siklus I dari 65,52\% ( 19 orang dari 30 orang) berada pada kategori kurang menjadi 86,21\% (25 orang dari 30 orang). Menunjukkan adanya perbaikan siklus I yang dilakukan pada tindakan siklus II.

Berdasarkan hasil analisis di atas, maka perlu adanya perbaikan dalam proses pembelajaran selanjutnya yaitu peneliti harus berusaha mengelola kelas dengan baik, harus memperbaiki cara-cara mengoptimalkan metode Problem Based Learning (Pbl) untuk dapat menjalani semua tahapan hingga peserta didik dapat mengambil kesimpulan sendiri dan dapat dengan mudah menjawab soal latihan yang ada pada bahan pembelajaran dan mengungkapkan pendapat terkait dengan materi pembelajaran.

Dalam proses pembelajaran dengan metode Problem Based Learning (Pbl) peneliti memberikan arahan dan bimbingan pada saat peserta didik menjalani semua tahapan metode Problem Based Learning $(P b l)$, membuat peserta didik semakin terarah dalam memberikan argumen maupun menjawab pertanyaan dari kelompok lain. Pada siklus II ini rata-rata pertanyaan yang diajukan audiens dapat dijawab dengan tuntas oleh setiap kelompok penyaji, karena persiapan yang baik dari setiap kelompok.

Pencapaian hasil belajar peserta didik sudah sesuai dengan yang diharapkan tidak lepas dari peran pengawasan peneliti dalam proses pembelajaran. Karena peneliti sebagai guru merupakan salah satu komponen yang mempengaruhi hasil belajar peserta didik . Pada siklus II terjadi perubahan-perubahan yang baik, hasil belajar peserta didik menjadi optimal, semangat belajar peserta didik meningkat, peserta didik aktif dalam proses pembelajaran, dan suasana pembelajaran menjadi lebih kondusif.
Pemberian latihan dan tugas dalam penelitian ini bertujuan untuk melatih kemampuan peserta didik agar peserta didik semakin paham dengan materi pembelajaran. Dari siklus I ke Siklus II, peneliti meningkatkan tindakan pemberian latihan dan tugas, ini disambut dengan baik oleh peserta didik. Tindakan perbaikan dari pemberian latihan ini membuat suasana pembelajaran dengan metode Problem Based Learning (Pbl) lebih interaktif. Selain itu peneliti juga memberikan motivasi kepada peserta didik sehingga peserta didik menjadi antusias untuk bertanya dan menjawab pertanyaan pada setiap tahapan memperesentasikan hasil dari setiap kelompok.

Penggunaan metode Problem Based Learning $(\mathrm{Pbl})$ dalam proses pembelajaran bertujuan untuk memberikan kemudahan bagi peserta didik dalam memahami materi pembelajaran dan menjadikan pembelajaran yang lebih menarik dan bermakna dalam meningkatkan hasil belajar teks prosedur. Dengan mengoptimalkan langkah-langkah dalam metode Problem Based Learning $(\mathrm{Pbl})$ pada siklus II membuat materi semakin mudah untuk dipahami peserta didik ketika menemukan konsep yang dipelajari dalam proses pembelajaran.

\section{Kesimpulan}

Berdasarkan hasil penelitian dan pembahasan, serta analisa data yang telah diuraikan pada bab IV dapat disimpulkan bahwa: Penggunaan metode Problem Based Learning $(\mathrm{Pbl})$ untuk pembelajaran bahasa Indonesia dengan jumlah enam kali pertemuan di kelas XI MM 1 SMK Negeri 7 Pekanbaru tahun pelajaran 2017-2018 dapat meningkatkan hasil belajar Bahasa Indoensia dari rata-rata 77,59 pada siklus I menjadi rata-rata 85,52 pada siklus II. Peningkatan hasil belajar siswa meningkat secara signifikan dengan adanya penambahan persentase siswa yang memperoleh nilai $\geq 82$ yaitu 19 orang dari 30 orang pada siklus I menjadi 25 orang dari 30 orang pada siklus II yang dikategorikan tuntas. Hal ini 
menggambarkan bahwa penggunaan metode Problem Based Learning (Pbl) untuk meningkatkan hasil belajar pembelajaran bahasa Indonesia sudah optimal di kelas XII IPS 1 SMK Negeri 7 Pekanbaru tahun pelajaran 2017-2018. Pembelajaran menggunakan metode Problem Based Learning ( $\mathrm{Pbl}$ ) memberikan hasil yang positif terhadap peningkatan hasil belajar siswa dibandingkan dengan menggunakan pembelajaran konvensional di SMK Negeri 7 Pekanbaru. Pada dasarnya penelitian ini berimplikasi positif bagi siswa dimana terlihat siswa akan lebih aktif, merasa percaya diri dan mandiri dalam mengikuti proses pembelajaran. Selain itu dapat juga sebagai pendorong bagi tenaga guru di SMA Negeri 2 Pekanbaru untuk memanfaatkan metode pembelajaran Problem Based Learning (Pbl) sebagai metode untuk menunjang proses pembelajaran.

\section{DAFTAR PUSTAKA}

Agus Irianto. (2003). Statistik konsep dasar dan aplikasi. Jakarta : kenvcana.

Anita Lie. (2004). Cooperative Learning: Mempraktekkan Cooperative Learning di Ruang-Ruang Kelas. Jakarta : PT. Grasindo.

Asep Herry Hernawan, et.al., (2011). Pengembangan Kurikulum dan Pembelajaran, Jakarta: Universitas Terbuka.

Asri Budiningsih. (2008). Pembelajaran Moral. Jakarta: PT Rineka Cipta.

Dimyati dan Mudjiono. (2006). Belajar dan Pembelajaran. Jakarta: PT Rineke Cipta.

Djamarah. (1994). Prestasi Belajar dan Kompetensi Guru. Surabaya : Usaha Nasional

Djamarah \& Zain. (2006). Strategi belajar mengajar. Jakarta: Rineka Cipta

Djamarah, S. B dan Zain, A. (2006). Strategi Belajar Mengajar. Jakarta: Rineka Cipta.
Eveline Siregar, Hartini Nara, 2010. Teori Belajar dan Pembelajaran, Bogor: Ghalia Indonesia.

Hamalik, Oemar.2010. Kurikulum dan Pembelajaran.Jakarta;Bumi Aksara.

Ibrahim, Muslimin, dkk. (2000). Pembelajaran Kooperatif. Surabaya: Unesa University Press. Surabaya.

Istarani. (2012). 58 Model Pembelajaran Inovatif. Medan: Media Persada.

Isjoni, (2009). Pembelajaran Kooperatif Meningkatkan Kecerdasan Komunikasi Antar Peserta Didik. Yogjyakarta: Pustaka Pelajar

Kunandar. (2011). Langkah Mudah Penelitian Tindakan Kelas sebagai Pengembangan Profesi Guru. Jakarta: Rajagrafindo Persada.

Nasution. (1995). Didaktik Asas-Asas Mengajar, Jakarta : Bumi Aksara

Nazir, Moh. (2009). Metode Penelitian. Jakarta: Ghalia Indonesia

Ratna Wilis Dahar, 1989. Teori-teori Belajar, Jakarta: Erlangga,

Ridwan, (2003).Dasar-Dasar Statistika.Bandung : Alfa Beta.

Rusman. (2012). Model-model Pembelajaran: Mengembangkan Profesionalisme Guru, Raja Grafindo Persada, Jakarta.

Sardiman A.M. (2011). Interaksi dan Motivasi Belajar Mengajar, Jakarta: Raja Grafindo Persada.

Silberman, Melvin L. (2007). Active Learning Strategi Pembelajaran Aktif. Yogyakarta: Pustaka Insan Madani.

Slameto. (2003). Belajar dan Faktor-faktor yang Mempengaruhinya. Jakarta: Rineka Cipta.

Subana, dkk. (2000). Statistik Pendidikan. Bandung, Pustaka Setia.

Sri Anitah W,et. al., (2007). Strategi Pembelajaran di SD. Jakarta: Universitas Terbuka 